\title{
Aristotelian Tragic Drama, Man and the Contemporary World: Pseudoclassicism in Ola Rotimi's Kurunmi
}

\author{
Uwem Affiah, Phd
}

\begin{abstract}
This essay examines Ola Rotimi's philosophical and artistic presentation of man as a tragic being. The essay avers that, perhaps, in the face of some contemporary world leadership problems, and in our continuous efforts to understand man, Ola Rotimi's pseudoclassicism as manifested in Kurunmi may provide some understanding of the problem. Adopting the formalistic approach out of Wilbur Scott's five approaches to literary criticism, the essay shows that Ola Rotimi's fidelity to the Aristotelian concept of tragedy is perhaps an attempt to explain some of the wonders of man's being as manifested in contemporary relations and leadership crises.
\end{abstract}

Key Words: Man, Aristotelian concept of tragedy, Kurunmi, tragic flaw, tragic vision, over-reach.

\section{Introduction}

There are several fundamental questions concerning man's existence in the cosmos begging for answers to this day. For example, is man a mere tool or puppet in the hands of a superior being? Is man helpless in life and is his life pre-ordained as for Oedipus in Sophocles' Oedipus Rex or Odewale in Ola Rotimi's The gods Are Not to Blame? Does man have a modicum of understanding of what his mission on earth is?

By his nature, man seems to have been endowed with intelligence, and the ability to speculate, conceptualize and rationalize. This is why he prides himself as being superior to all other creatures on earth. In spite of these, the affairs of his life, in most cases seem to be beyond his control. His actions often appear to have been poorly thought-out and irrational. His behavior and actions surprise those around him. A careful observation of man brings one to the conclusion that he is controlled either by very powerful instincts within him, which he is incapable of regulating or by some powerful forces external to his being. As Oso (1978) puts it "... man, in his earthly life, believes that he is in the hand of the Deity...." (77).

It seems reasonable to believe that realizing man's perculiar circumstances, the ambiguities of his existence, the incongruities of his values and concepts, tragic drama, then was invented by the ancient Greeks as a means of illuminating man's behavior, firm up his beliefs, provide alibi for his limitations and recompense his ego which is usually deflated by the consequences of his irrationality. Thus, tragic drama is concerned with what happens when a person over-reaches himself, the inner turmoil leading to and arising from over-reaching oneself and how man bears the passions arising therefrom.

Theatre and literary historians such as Robert Cohen (2003), Oscar Brockett (1995) and Bernard Dukore (1974) aver that tragic drama as an artistic medium, evolved in Greece in the $5^{\text {th }}$ century B. C. Adrian

Roscoe (1978) asserts that:

"Tragedy was utilized to eschew the pains and frustration, the agonies of disappointment and disillusionment, and the inexplicable blunders which often lead to suffering in human experiences, both as a spiritual and social being" (35).

This essay attempts to find answers to man's attitudes, behavior and actions with regards to the negative tendencies which strain human relations and interactions. Of particular interest is how these tendencies have affected contemporary world governance and peace.

Ola Rotimi's Kurunmi was chosen to illustrate the point because a cursory reading of it reveals a protagonist whose life, behavior and actions give credence to the points raised in this introduction. A thorough analysis will go on to synchronize with Aristotle's concept of tragedy, a concept which Rotimi adheres to, seemingly because it explains the incongruities, contradictions and inexplicable actions of man.

Why, for example, would a Jonas Savimbi in Angola, against all entreaties vow to wage war against his country until death? Why will a Laurent Gbagbo in Cote D'voire, against good reason, refuse to respect the outcome of an election in which his countrymen elected his opponent and opt instead to throw his country into war? Why will a Ghaddafi in Libya reject all offers of asylum for peace to reign in Libya and in sist that after over four decades in the saddle he remains the only one capable of leading Libya? Why will Assad of Syria prefer a devastating war to quitting office after over four decades? Why will an Olusegun Obasanjo want to amend the Nigerian constitution in order to pave way for a third term in office after exhausting the constitutional two terms and in spite of the mood of the nation which was clearly against his third term bid?

Man is, indeed, a wonderful animal. Wonderful in his reasoning, thoughts, behavior and actions. Tragic drama is an attempt to proffer explanations and understanding of man's nature and being. 


\section{The Aristotelian Concept Of Tragedy}

After the emergence of the tragic genre as a dramatic art form, the first detailed study of it was carried out by Aristotle and his findings are presented in his Poetics. Dudley and Lang (1969) state that Aristotle defines tragic drama as:

...tragedy is the representation of a series of events in which the hero, who is neither saint nor villain, brings disaster on himself through error, and not through accident or wickedness; and disaster should come about unexpectedly through a sudden change of circumstances, or recognition of someone hitherto or better still both together ... (168).

In Dorsch's (1965) translation of the Poetics the definition is stated thus:

Tragedy, then, is the representation of an action that is worth serious attention, complete in itself, and of some amplitude; in language enriched by a variety of artistic devices appropriate to the several parts of the plays; presented in the form of action, not narration, by means of pity and fear bringing about the purgation of such emotions (38 - 39).

Implicit in Aristotle's definition is the notion that the tragic protagonist is a man of high standing brought from prosperity to adversity as a result of some great error or frailty. Succeeding critics have crystallized this into the hallowed theories of the tragic hero, the tragic flaw, the tragic spirit and the tragic vision. The tragic character is tightly and rigidly bound by his emotion and his desire to stand firmly by whatever decisions he has taken.

There is always a flaw in his character known as the tragic flaw. It is this flaw which inspires him to initiate the tragic action which is meant to be a means of reaching whatever objective his tragic vision has produced. There is something in man which makes him prone to weakness and error. Whatever that is, it is regarded as the tragic spirit. The tragic spirit is what infuses the tragic protagonist with the tragic flaw. It is this spirit that infuses him with the conviction that convinces him to dedicate himself to achieving the objective produced by his tragic vision. According to Krieger (1963), "tragic vision is a subject's psychology, his view and version of readily" (131). It is the hero's goal which he pursues with all his concentration and emotion.

Perhaps Richard Sewall (1962) puts if better when he says "that tragic vision impels the man of action to fight against his destiny, kick against the pricks, and state his case before God or his follow ...." (37). It seems, therefore, that following their tragic visions the likes of Saddam Hussein, Ghadafi, Laureant Gbagbo, Jonas Savimbi, and many others like them, fight against destiny, kick against the pricks and come to catastrophic ends.

The tragic action once initiated must run its full course. It is irreversible. It obeys the law of cause and effect. In addition, bound by his psychology, his version of reality, the tragic hero, resists everything and every effort aimed at persuading him to abandon his tragic vision. Thus, blinded by his tragic vision, he heads for a tragic end which seems inevitable and unavoidable. This implies a tragic destiny.

Therefore, man, a tragic hero, seems to be an embodiment of a tragic spirit, a tragic flaw, and a tragic vision all of which compel him to initiate a tragic action. The tragic action obeys the law of cause and effect and so must run its course. In addition since man must fulfill his tragic destiny, he resists all entreaties and persuasion to turn back.

\section{Kurunmi: A Reflection Of Contemporary Leadership Challenges}

The plot of the play is derived from the Ibadan - Ijaiye are of the $19^{\text {th }}$ century. According to Rotimi(1971): In 1858 Alafin Atiba, sensing that he was soon to die, called his leading chiefs to get them acknowledge the Crown Prince, Adelu, as his successor. This move was contrary to the constitution of Oyo, which required the Aremo or Crown Prince, who enjoyed great power while his father ruled, to commit suicide on the Alafin's death. Ibadan supported Alafin Atiba's move... Ijaiye, under Kurunmi opposed the Alafin's decision as contrary to tradition. (7-8).

The play, kurunmi, tells the story of the conflict and war that arose between Ibadan and Ijaiye as a result of their respective decisions, with the Egba coming in on the side of Ijaiye.

Indeed, the play, "Kurunmi creates the turbulent rhythms or war to match the explosive clash of wills that brought about the grueling Ijaiye war of the $19^{\text {th }}$ century." (See the blurb of the play.)

The play revolves around Kurunmi, the Are-Ona-Kakanfo of the Oyo Empire and supporter of tradition and the chiefs of Ibadan led by Ibikunle, supporter of change. In defence of tradition, kurumi drags his people into a ruinous war, brings untold hardship on his tribe and fights to his doom. The play is dominated by Kurunmi. His career provides suitable material for a tragic hero, a man fighting a war for reasons he believes to be just; he fails because he makes a fatal error of judgment resulting from a fault of character, and also because he is pitched against more powerful forces. His career is a reflection of the career of many men and women in leadership positions in various countries across the world. Kurunmi's career gives us an insight into the psychology, mentality and mind set of many of these people. 
Kurunmi is stubborn and adamant as a result of personal pride. He is jingoistic and very monolineal in his fixation and believes in the propriety of his, and only his own opinion. Therefore, the playwright presents us a tragic hero with a tragic flaw along the lines of Aristotle's postulations.

What makes_Kurunmi an attractive play is the way it uses the facts of history to dramatize the social realities of the present. In the words of Johnson (1982)

... The conflict was due as much too divergent views on tradition and the constitution as to factionalism, personal jealousies and rivalry ... (67).

The play traces the conflict of personalities and the course of the war right up to Kurunmi's death. Rotimi approaches his work from the angle of tragedy. Kurunmi, the tragic hero, answers to the historical description of "King, Judge, General, Entertainer, sometimes also, executioner (Ajayi 1964:67).

In the words of Oladele Taiwo(1986) the hero "is presented in a way that his acts and speeches easily attain tragic proportions. His initial moves are utterly convincing" (6). As Are-Ona-Kakanfo, he cannot allow tradition to be flouted with impunity,

Kurunmi: ... The day a people lose their tradition is the day their death begins - weeds, they ... (Kurunmi 16).

Kurunmi says this in justification for his preparation for war. He is at pains to emphasize that his hatred for Adelu and his supporters does not stem from any personal consideration but from his obligation to uphold tradition which, to him is crucial to group survival,

Kurunmi: ... My people, we too have tradition. This is what makes us men. This is what makes us ... people, ... The pride of man, my people, is in his tradition... (Kurunmi 15 - 16).

Kurunmi's goal, the objective he hopes to achieve by going to war is the maintenance and preservation of tradition. He believes that it is incumbent on him to protect tradition. This is his tragic vision and the result is bound to be the opposite of the objective itself.

One achievement of the work is the way Rotimi brings before the reader the seriousness of the situation. We are made to see a great deal of the preparations for war on both sides. The occasional disagreement within the two warring camps of Ijaiye and Ibadan is realistic in the circumstance. According to Taiwo (1986) "Rotimi succeeds in evoking a gloomy atmosphere of war in which each side uses every kind of ruthless device, traditional or modern, to wipe out the other" (59). This is an obvious reference to the tragic atmosphere of the play.

Actually, the moment the Are-Ona-Kakanfo opposes the choice of Adelu as successor to Alafin Atiba, there is tension in the atmosphere. The atmosphere continues to gather tension as Kurunmi choses war rather than consultation and as preparations for war begin.

The moment of the initiation of Kurunmi's tragic action is the moment when he opts for war instead of consultation and negotiation. The Alafin's messengers present him with two options, those of peace or war as symbolized by the sacred twins of the Ogboni Cult and the bowls containing bullets and gun-powder respectively ( Kurunmi Act 1, Scene 3, 26-27).

Having initiated this tragic action, Kurunmi continues to grow, according to the demands of the action, to the limits of his possible development, the exhaustion of his powers and then is overtaken by calamity.

The war is not just a fight between men; the gods are involved, and with equal acrimony they play their part. Nonetheless, the psychological climate that calls for the intervention of the gods is created by man. Areagoro tries to achieve this for Ijaiye in the following lines:

Areagoro: Ogun Onire ... Sango ... Ogun ... Lord of battle it is to you we call, and before you we stand. It is ... (Kurunmi, 60).

In reporting the events of the war, Rotimi exercises great economy of words. Each encounter between the warring factions carries the action of the play forward. Also, he makes no attempt to recall encounters; rather he cleverly uses the diary of Mr. and Mrs. Mann in Act 3, Scenes 5 and 9 to fill in the necessary details. In doing this he excludes material which may have been boring. Akanji Nasiru(1979) commends the playwright for this technique:

Althogether, Rotimi has been careful not to divert attention from the main concern of the play. The series of battle that take place in act three

are all important aspects of the historical event, but the playwright's intension is not to recount the facts of history. Rather he is interested in the study of man caught up in a particular situation (26-27).

The importance of the battles is that they help focus attention on the tragic irony, Kurunmi's changing fortunes, before the final blow that spells his doom. The final blow comes with the defeat and disgrace of Kurunmi's forces and his eventual downfall.

Kurunmi's desire is to disgrace the Alafin and the Ibadan Lords and in the process protect and preserve tradition. Says he:

When the tortoise is heading for a senseless journey, and you say to him: 'Brother Tortoise, when will 
You be wise and come back ...' The tortoise will say... Not until I have been disgraced'. (Kurunmi, 17).

This is a reference to his opponents and the disgrace they will suffer from him. However, it turns out to be a tragic irony since Kurunmi is the one on a senseless journey. He is the one heading for a disgrace, which he actually gets in the end. What he gets in the end is contrary to his expectations. His situation changes from good to bad as he falls from grace to grass. Tragic irony as used here exposes Kurunmi's error, to have opposed the collective wish of the state and opt for war to settle the problem.

In Kurunmi, Ola Rotimi explores the following themes: collective political and military leadership; social change and development, responsible leadership; control and accountability. By focusing of these, he is able to inject contemporary socio - political relevance into the historical subject of the play.

From the historical perspective, the play deals with social change and development in a traditional society. Oyo had developed to a point which demanded a change or modification of tradition to "facilitate adaptation in the face of encroaching modern values and western power" (Johnson 1982:141). Kurunmi, arcconservative opposes any change or modification and rejects progress in the name of tradition. His justification for his actions is untenable and mistaken:

... When the gabon viper dies, its

Children take up its habits, poison

And all. The plantain dies, its

Saplings take its place, broad

Leaves and all. The fire dies, its

Ashes bear its memory....

(Kurunmi, 15$)$.

These analogies refer to natural phenomena "which are renewing and life - sustaining through their cycle of death, birth, and growth, and are not sterile and immutable like his conception of tradition" (Johnson 1982: 144).

Kurunmi: we have tradition, and

Tradition is tradition. Time may

Pass but the laws of our fathers

... Live on. That is tradition.

(Kurunmi, 20).

This is his own version of reality and it is what instructs his tragic vision - tradition must be protected and preserved. No change can be tolerated.

Kurunmi is averse to dialogue and negotiation, consultation and discussion, imposing his personal judgment and will on the state. He impatiently dismisses the other leaders, showing little regard for their genuine concern over Ijaiye's military unpreparedness for war. Kurunmi "is the jingoistic kind of leader ... very unbending on what he alone considers right" (Rotimi 1991: 7). This attitude of his causes a temporary rebellion as it breeds resentment (see Kurunmi ${ }_{2}$ p.39). As a contemporary play Rotimi rejects Kurunmi for not being a good leader.

Kurunmi has the stature, followership and resources to challenge the collective decision of the state - and this he is prepared to do. Thus, he becomes a threat to the society by virtue of his arrogance and reckless use of power. Those who support the Alafin and oppose Kurunmi represent social change and accountability both of which Kurunmi rejects.

The introduction of white characters has been regarded as flaw on the part of Rotim. Notwithstanding, the Manns serve a purpose as Kurunmi's rejection of Rev. Mann's Christian doctrine, at a time when Ibadan and others had accepted the faith, emphasizes his rigid stand on tradition. Rotimi also uses them to achieve an economic use of words as they comment on the flow of the conflict and report developments in the battle field at crucial stages.

Just as he has been careful in selecting his materials, Rotimi, also, pays great attention to the appropriateness of language to the action which he depicts. Language plays an important role in the play. Apart from using it to delineate characters, Rotimi, through language, develops an idiom close to African speech. What we have in the play as Johnson (1982) avers is an "English verbal register containing proverbs, figures of speech, special idioms, expressions...." (146). The use of language to delineate character can be seen between Kurunmi, on the one hand, who uses proverbs, figures of speech, special idioms and expressions, and the two Ibadan leaders who, on the other hand, use these to a lesser extent.

The character most distinguished by language is Kurunmi. All through the play. He switches consistently from verse to prose and back depending on the specific roles he plays at any given moment or the experience which he feels as for example, the use of verse during the pouring or libation or during the invocation of spiritual support at his agbo' Ie (compound). There is a preponderance of animal terms in his vocabulary, used either literally or figuratively to show scorn and contempt:

The frog is kicked - kpa!

It flattens

y-ak-at-a- on its back.

We shall all die 'gbere ...

(Kurunmi 27-28).

Besides showing contempt for his opponents through the use of such language, it is also used to provoke laughter that is comic interlude. 
Though comic interludes are not accepted in tragedies by Aristotelian standards, it is almost unavoidable, derived as it were from the Yoruba sense of humor. The way the playwright juxtaposes tragic and comic elements portray his indebtedness to oral tradition.

The words 'kpa', 'y-a-k-a-t-a' and 'gbere' are ideophones. They help to underline Kurunmi's miscalculation and accentuate his tragic action.

The play carries an emphasis an African theatre as can be seen from the abundance of traditional elements such as song, dance, mass and individual movements and ritual libation which all add to the spectacle.

Kurunmi's tragic destiny is fulfilled when his forces are defeated and with this fulfilment comes his tragic recognition in the following lines:

Kurunmi: when a leader of men has

Led his people to disaster, and

What remains of his present life

Is but a shadow of his proud past

Then .....

(Kurunmi, 93).

This is his realization of the fact that he has committed errors, that he has unnecessarily led his people to disaster and that this is the result of pride - stubborn pride.

As a tragic hero with a tragic flaw, Kurunmi is filled with the tragic spirit since it is this spirit that infuses him with the weakness called the tragic flaw.

Whether the hero of this play excites our earnest goodwill is a difficult one to answer, just as it is difficult to say whether or not his action was born out of good intensions and sincerity of purpose.

\section{Conclusion}

We have seen that it is in the nature of man to behave the way he does and to do the things he does. It is just his nature. The world is full of wars, hunger and starvation, terrorism, and all manner of crises as a result of many Kurunmis in positions of leadership at various levels in many countries. The higher the position of leadership, the more severe the consequences of the leader's action.

However, we cannot accept behaviour and actions that bring untold hardship, pain, suffering and sorrow to man with utter resignation as if there is nothing that can be done about it.

We have seen, also, that whereas there are animals stronger than man, others with a better sense of sight, others much faster and others with a stronger sense of perception man still prides himself as God's most superior creation. This feeling of superiority over all other creatures arises from man's ability to speculate, conceptualize and rationalize.

Apparently, psychologically and emotionally, man seems to have two selves: the rational and irrational. These two selves seem to be perpetually in conflict with each other. Pain, misery, untold hardship, suffering and sorrow are usually the outcome when the irrational self overpowers the rational self.

Kurunmi appears to be ungovernable, unteachable, barbaric, merciless, crude and uncouth only because he allows the irrational self to overpower the rational self.

$\mathrm{He}$ is jingoistic, rigid and proud. He is monolineal in fixation and averse to dialogue, consultation and discussion. $\mathrm{He}$ is contemptuous of the people and opposes their collective wish and to crown it all he is reckless with the use of power. The end can only be tragic for him, his people and mankind in general.

At whatever level of leadership a man finds himself, is it the level of the family, the village, the state, the nation, or the world, the defining characteristics of rationality must reign, namely: patience, tolerance, humility, sincerity, circumspection, etc.

The individual, the nation and the world would have been spared pain, sorrow, suffering and hardship if the Saddam Husseins, Gaddafis, Gbagbos, Idi Amins, Mobutus, Mugabes, Bothas, Bin Ladens and their likes were more rational than irrational.

\section{Works Cited}

[1] Ajayi, J. F. A. Yoruba Warfare in the Nineteenth Century. London: EUP, 1967.

[2] Amuta, C. The Theory of African Literature: Implications for Practical Criticism. London: Zed Books, 1989.

[3] Brockett, O. G. History of the Theartre. Boston: Allyn and Bacon, 1995.

[4] Cohen, R. Theatre: Brief Version. Boston: McGraw-Hill, 2003.

[5] Dorsch, T. S. (tans.) "Poetics". Classical Literary Criticism: Aristotle, Horace and Longinus. Hammondsworth: Penguin Books, 1965.

[6] Dudley, D. G. and D. M. Lang (ed). Penguin Companion to Literature. Hammondsworth: Penguin Books, 1965.

[7] Dukore, B. F. (ed). Dramatic Theory and Criticism: Greeks to Grotowski._New York: Holt, Rinehart and Winston, 1974

[8] Etherton, M. "Trends in African Theatre". African Literature Today No. 10. 1980.

[9] John, A. "Ola Rotimi: How significant." African Literature Today No.12 1982.

[10] Krieger, M. "Tragic and the Tragic". Tragedy: Modern Essays in Criticism. Connecticut: Green wood Press Publishers, 1963.

[11] Nasiru, A. "Ola Rotimi's Search for a Technique”. New West African Literature. London: H. E. B., 1979.

[12] Oso, S. O. An Introduction to West African Traditional Religion. Ado-Ekiti: Omolayo standard company Limited, 1978.

[13] Roscoe, A. Mother is Gold. London: Cambridge University Press, 1978.

[14] Rotimi, O. Kurunmi. Ibadan: University Press Limited, 1971.

[15] Scott, W. Five Approaches of Literary Criticism. New York: Collier Macmillan Press, 1962.

[16] Sewall, R. "The vision of Tragedy." Tragedy:Vision and Form. London: chandler publishing company, 1962.

[17] Taiwo, O. Social Experience in African Literature. Enugu: Fourth Dimension Publishing Company Ltd, 